\title{
OBITUARY
}

\section{REMINISCENCES OF SABIR YUNUSOVICH YUNUSOV}

Uzbekistan science has suffered a grievous loss. Professor Sabir Yunusovich Yunusov has died in his 86th year. He was an outstanding scientist, Academician of the Academy of Sciences of Uzbekistan, Corresponding Member of the Russian Academy of Sciences, Honored Scientist of Uzbekistan, Laureate of the al-Biruni State Prize, Member of the Leopoldina Deutsche Akademie der Naturforscher, and Doctor of Chemical Sciences.

The whole life of Sabir Yunusovich - a remarkable man and a scientist of world renown - was devoted to investigations in the field of the chemistry of natural compounds. By his discoveries he made an inestimable contribution to world science.

S. Yu. Yunusov was born in 1909. In 1935 he graduated from the Central Asian State University and took up postgraduate studies at the Moscow Institute of Pharmaceutical Chemistry, where he defended his Candidate's dissertation under the direction of A. P. Orekhiv in 1939 and continued to work as a Senior Scientist.

Sabir Yunusovich took part in the Second World War. In 1943 he created a laboratory of alkaloid chemistry in the Institute of Chemistry of the Uzbekistan Academy of Sciences. He defended his doctoral dissertation in 1949. The achievements of the laboratory made it possible for him in 1959 to set up the Institute of the Chemistry of Plant Substances, of which he was the director until 1983. A scientist's dream came into being - within the walls of a single institute the main classes of natural substances are being comprehensively studied and problems of the interrelationship of the structures of natural substances and their functions and biological effects are being solved. The main work of the scientist was the training of highly qualified specialists. The school that he created numbers more than a hundred Doctors and Candidates of Science. He established groups commanding modern physical and chemical methods of investigating natural compounds, and created laboratories of pharmacology, toxicology, technology, etc., which are permitting scientific developments to be brought to practical completion.

Sabir Yunusovich Yunusov was the founder of the journal Khimiya Prirodnykh Soedinemii [Chemistry of Natural Compounds] and was its Editor-in-chief up to and including 1992. He had previously been Vice-President of the Uzbekistan Academy of Sciences and Academic Secretary of the Division of Technological Chemical Sciences. In later years, Sabir Yunusovich was honorary director of the Institute of the Chemistry of Plant Substances of the Academy of Sciences of the Republic of Uzbekistan.

For great service in the development of science, the title of Hero of Labor was conferred upon S. Yu. Yunusov, and he was awarded numerous orders and medals. He received the D. I. Mendeleev Gold Medal for investigations in the field of alkaloid chemistry.

The memory of a remarkable scientist and teacher, and a man of great spiritual charm and personal modesty will always remain in the hearts of all who knew him.

Sabir Yunusovich Yunusov's life's work is being worthily continued and developed by his pupils.

Translated from Khimiya Prirodnykh Soedinenii, No. 6, p. 918, November-December, 1995. 